Marquette University

e-Publications@Marquette

College of Nursing Faculty Research and

Publications

Nursing, College of

$1-2019$

\title{
A New Leadership Development Model for Nursing Education
}

Jane M. Miles

Elaine S. Scott

Follow this and additional works at: https://epublications.marquette.edu/nursing_fac

Part of the Nursing Commons 
Marquette University

e-Publications@Marquette

\title{
Nursing Faculty Research and Publications/College of Nursing
}

This paper is NOT THE PUBLISHED VERSION; but the author's final, peer-reviewed manuscript. The published version may be accessed by following the link in the citation below.

Journal of Professional Nursing, Vol. 35, No. 1 (January/ February 2019): 5-11. DOI. This article is (C) Elsevier and permission has been granted for this version to appear in e-Publications@Marquette. Elsevier does not grant permission for this article to be further copied/distributed or hosted elsewhere without the express permission from Elsevier.

\section{A New Leadership Development Model for Nursing Education}

Jane M. Miles

Marquette University College of Nursing, Milwaukee, WI, United States of America

Elaine S. Scott

East Carolina University College of Nursing, Greenville, NC, United States of America

\begin{abstract}
Background

Leadership competency is required throughout nursing. Students have difficulty understanding leadership as integral to education and practice. A consistent framework for nursing leadership education, strong scholarship and an evidence base are limited.

\section{Purpose}

To establish an integrated leadership development model for prelicensure nursing students that recognizes leadership as a fundamental skill for nursing practice and promotes development of nursing leadership education scholarship.
\end{abstract}




\section{Method}

Summarizing definitions of nursing leadership, conceptualizing leadership development capacity through reviewing trends, and synthesizing existing leadership theories through directed content analysis.

\section{Discussion}

Nine leadership skills form the organizing structure for the Nursing Leadership Development Model. Leadership identity development is supported via dimensions of knowing, doing, being and context.

\section{Conclusion}

The Nursing Leadership Development Model is a conceptual map offering a structure to facilitate leadership development within prelicensure nursing students, promoting student ability to internalize leadership capacity and apply leadership skills upon entry to practice

\section{Introduction}

Few nurses would argue that practice innovation, quality improvement, and effective care delivery require leadership. Nursing education literature suggests a heightened awareness of the need for leadership, as well as a wide variety of pedagogical approaches for developing leadership skills in nurses (e.g., Curtis, de Vries, \& Sheerin, 2011; Curtis, Sheerin, \& de Vries, 2011; Yoder-Wise, 2012). Some pedagogical approaches in use include application of the Active Learning Model (Middleton, 2013), service learning (Foli, Braswell, Kirkpatrick, \& Lim, 2014) clinical integration (Pepin, Dubois, Girard, Tardif, \& Ha, 2011), simulation experiences (Pollard \& Wild, 2014) and the use of the social justice framework (Waite \& Brooks, 2014). The American Association of Colleges of Nursing (AACN) has acknowledged the criticality of leadership development in both the baccalaureate and master's educational essentials (American Association of Colleges of Nursing, 2008, American Association of Colleges of Nursing, 2011). Realities such as the rate of change in health care, staffing shortages and the heightened focus on quality care intensify this perspective and create a need to take full advantage of the nursing education years to begin development of leadership capacity in nurses, beginning early in baccalaureate level education.

The Institute of Medicine (IOM) report on the Future of Nursing deemed leadership competencies essential, identifying the complexity of patient care requirements and the demand for quality as the driving factors (IOM, 2011). Competencies identified included knowledge of care delivery, ability to work in teams, ability to address complex quality improvement needs, and knowledge of economics (IOM, 2011). There is a need to augment nurses' understanding of their practice and the role of nursing within health care systems such that, in addition to clinical interventions, leadership is perceived as a significant dimension of what the profession does ( $\underline{\text { Curtis, }}$ de Vries, \& Sheerin, 2011).

The American Association of Colleges of Nursing, 2008, American Association of Colleges of Nursing, 2011 and the IOM report (2011) view leadership as both a process and a role. Leadership ability is an essential component of both administrative and clinical practice. Transitioning from a perspective of leadership in nursing as a role to one that also embraces leadership as a process used by and taught to all nurses is essential for meeting the challenge of a constantly transforming health care delivery system (Scott \& Miles, 2013). Conceptualizing leadership in nursing as both an influencing process and a formal role allows for incorporation of emergent concepts such as interdisciplinary leadership and clinical leadership into the broad scope of nursing leadership.

Despite the growing acknowledgement of a need for leadership development in all nurses, limited evidence or strong scholarship exist about which nursing leadership competencies are critical and how nursing leadership capacity can be developed. Nursing leadership education courses have demonstrated the beneficial use of theories and guidance established by other disciplines to design leadership courses (e.g., James, 2010; Pollard \& 
Wild, 2014; Waite \& Brooks, 2014). However, no leadership development model established specifically for nursing was found. Such a model would account for the unique practice and education standards of nursing yet allow other disciplinary theories to be used as content within an educational approach tailored for prelicensure nursing students. External to nursing, research was conducted to establish a leadership development model and create a knowledge base for use in business education, as well as to promote a "community of practice" in support of leadership education (Snook, Nohria, \& Khurana, 2012, p. xiv). Recognizing the value that such a model would offer to nursing education, a synthesis process to construct a leadership development model for nursing education was undertaken.

\section{Methods}

Multiple methods were used in the process of model development: 1) summarizing definitions of nursing leadership, 2) conceptualizing leadership development capacity in nursing through review of trends in leadership development, and 3) using directed content analysis to synthesize and integrate existing theories of leadership in a format applicable to nursing.

Throughout the process, the authors' extensive backgrounds in leadership and in leadership development, including roles of leaders in health systems and teachers of leadership in formal baccalaureate and graduate programs, had substantive influence on the thinking and conceptualizing leadership development and development of the synthesized model. A hermeneutic process of circular reflection (Parse, 2001) linked the three phases of the development process.

\section{Phase I. Defining nursing leadership}

Leadership has existed since the earliest of times and in all societies. Yet, despite multiple models and extensive examination of the concept, attempts to define leadership have remained elusive both within nursing and other disciplines. Addressing the future of nursing more than a decade prior to the IOM (2011) report, Grossman and Valiga (2000)described common elements in the leadership literature, such as vision and communication skills, and they defined leadership essentially as a process that connected those elements. They framed the need for leadership in nursing in terms of the ever-changing environmental context of health care.

An early review of the literature on nursing leadership in formal roles noted four essential dimensions of leadership (Cummings et al., 2008). The dimensions encompassed the concepts of process, influence, group setting or context, and vision (Cummings et al., 2008). A subsequent extensive review by Northouse (2013) of over 65 leadership classification systems, approaches to leadership in terms of traits, skills, styles, and situations, and six major leadership theories resulted in identification of four foundational leadership components: (a) leadership is a process, (b) leadership involves influence, (c) leadership occurs in groups, and (d) leadership involves common goals (Northouse, 2013).

Bleich's (2011) discussion of leadership included influencing others and facilitating shared objectives, similar to the views later expressed by Yukl (2012). Leadership in the nursing profession was defined as a "process of engaged decision making linked with actions taken in the face of complex, unchartered, or perilous circumstances present in clinical situations for which no standardized solution exists" (Bleich, 2011, p. 5).

The complexity of the current healthcare environment, the extent of health disparities, and the frequency of change within that environment have created a situation that Day and Harrison (2007) asserted moved beyond the view of a traditional leadership structure. Theories of leadership established since the year 2000 , have suggested that contemporary leadership is a dynamic social process, referred to in a variety of ways including shared leadership (Cox, Pearce, \& Sims, 2003; Pearce \& Conger, 2003), collective leadership (Day, Gronn, \& Salas, 2004), and relational leadership (Uhl-Bien, 2006). Evolution into the age of knowledge and technology has 
made information accessible to all, and in return has allowed leadership to emerge among all group members. Research has also demonstrated that shared leadership contributes to a sense of personal empowerment and satisfaction, positive group behavior, and outstanding organizational financial performance (Wassenaar \& Pearce, 2012).

These perspectives in leadership thought reinforced the need to establish a definition of leadership relevant for nursing students that would apply from the beginning of the education process into practice. An operational definition of leadership in nursing was developed to guide model development: Leadership in nursing is a social and relational process of positive influence and engaged decision making linked to actions and attitudes that benefit nursing, patients, and the healthcare environment (Bleich, 2011; Grossman \& Valiga, 2000; Northouse, 2013; Uhl-Bien, 2006; Yukl, 2012). This definition addresses the changing realities of the profession and guided the subsequent conceptualization of a theoretical model of leadership development.

\section{Phase II. Conceptualizing development of leadership capacity}

Defining leadership is but one aspect needed in a theoretical model for the development of leadership in nurses. Theories that explore how leadership ability and identity are cultivated in an individual must also be considered (Scott \& Miles, 2013). The term capacity has been used to identify the goal of leadership development in individuals over time (Day \& Harrison, 2007). A recent review of trends in leadership development affirms significant change in the content and processes used (Center for Creative Leadership [CCL], 2014). Four transitions were identified: 1) a movement to collective leadership development spread throughout a system, 2) a shift from organizational to personal accountability for leadership development, 3) a need to develop both a sense of being a leader (vertical development) and the knowledge and skill to lead (horizontal development), and 4) a movement from a simple focus on learning what leadership is to teaching the means through which leading occurs (CCL, 2014). These transitions support calls within the industry to refocus from leader role development frameworks in nursing to leadership development frameworks such that all levels of nurses can develop capacity for leadership (Scott, 2010).

To develop leadership, those who are in the process of doing so must gain knowledge, become self-aware as a leader, and take action (Komives, Lucas, \& McMahon, 2013). These focal areas, or dimensions, of knowing, doing and being, were also included in the organizing framework for teaching leadership developed by Snook et al. (2012). The dimensions were defined as the need for knowledge regarding leadership processes and theories, the ability to carry out the processes, and the ways that leaders approach the world via their character and unique perspectives. An additional dimension for teaching leadership, context, was included. The model for leadership development described by Snook et al. (2012)is comprehensive, characterizing the process as promoting vertical development that fosters an internal sense of becoming a person capable of leading (being), as well as defining what leading is (knowing), and how best to lead and influence in varying situations and contexts (doing and contextual intelligence).

A review of diverse literature from the areas of administration, business, nursing, sociology, and organizational psychology was conducted to affirm that knowing, doing, being, and context were the essential dimensions needed in a leadership development model relevant for nursing. In the business literature, the concepts of "leaders, followers and situations" were identified (Day \& Harrison, 2006, p. 457). Day and Antonakis (2012) reduced leadership to two common elements that often guide research and education. First, leadership was described as an influencing process, and secondly, the impact of that influencing process was related to the interaction of the being element, the follower's viewpoints, and the context. This issue was first noted by Avolio (2007), who contended that leadership science often highlights individual competency development without considering followers and context. While the essential status of follower consideration has been accepted, leadership theorists have argued whether leadership is bound to context (Antonakis, Avolio, \& 
Sivasubramaniam, 2003). Theories of leadership either adopt a perspective that ignores context or one that acknowledges its role in the leadership process. However, research has demonstrated that contextual variables often moderate leadership (Antonakis et al., 2003).

Prelicensure nursing students may enter the nursing education program with experience in leadership gained through previous employment, life experience, or in student organizations. However, they are likely to have limited knowledge, or direct experience, of leadership in nursing. The authors of this article maintain that, when working with prelicensure nursing students, there is a need for a specific leadership development framework incorporating the dimensions of knowing, doing, and being. Such a framework would take into consideration distinct personality or individual characteristics, promote the view that leadership is integral to being a nurse, and support designing pedagogies specifically targeting the competencies needed within each dimension. Additional theoretical knowledge, such as recent recommendations for incorporating promotion of systems thinking as part of leadership education (Phillips, Stalter, Dolansky, \& Lopez, 2016) would then become a component of a leadership curriculum based on the framework. Additionally, rather than viewing leadership as only a role, incorporating the dimension of context (Snook et al., 2012) in this framework would support students in developing understanding and value for leadership within the multiple contexts of nursing.

\section{Phase III. Synthesis of the Nursing Leadership Development Model}

Donaldson and Crowley (1978) proposed that the ways in which the science and methods of other disciplines can inform nursing science be considered. Despite a large body of research on leadership and leadership development in other fields, its application and relevance in nursing has not been thoroughly explored. Most often nurses use theory borrowed from other disciplines to guide research and education on the concept of leadership (Cummings et al., 2008).

To respond to the IOM's (2011) recommendations for developing leadership capacity in all nurses and to construct a testable theory for developing leadership in nurses that can be implemented and measured in prelicensure nursing education, consideration must be given to existing theoretical frameworks that can be used to synthesize a model to guide accomplishment of these goals in the discipline. No existing theoretical framework could be found that fully integrated Snook et al.'s (2012) recommendations for the knowing, doing, being, and context elements of a leadership development program; however, many theories were available for describing and testing the respective elements of the model. This led to the determination that integration of these theories might create a model of leadership development for nursing students that would satisfy the needs of both researchers and educators in nursing.

Theoretical integration brings together related theories, identifying common variables and relationships, thereby allowing for improved ability of the newly integrated model to explain both commonalities and variation (Muftic, 2009). The integration of leadership theories is useful in addressing a multitude of research questions that often cannot be answered through one theory alone (Avolio (2007).

Conceptualizing Knowing and Doing in nursing leadership

To determine the elements of knowing and doing in nursing leadership, eight best-selling nursing leadership textbooks used to teach nursing leadership were reviewed. Since the context for model development was to advance the capacity of nursing students to use leadership skills, the publisher summaries of the texts were screened to determine texts that considered leadership to be a process rather than just a formal role. Based on this evaluation, five of eight texts were reviewed. Review of these references yielded four primary leadership frameworks that ascribed the knowledge and skills (knowing and doing) necessary for leading: Bass's Transformational/Transactional Leadership (1985), Gardner's Tasks of Leadership (1990), Yukl's Framework for Leadership (2012), and Kouzes and Posner's Leadership Practices (2007). Table 1provides a summary and comparison of these four major theoretical views on the components of leadership. Dates indicate theory 
origination. While wording may have changed, similarities and stability in concepts over time is indicated by the arrangement of the concepts across the table.

Table 1. Theoretical frameworks of leadership from undergraduate nursing textbooks.

\begin{tabular}{|c|c|c|c|c|}
\hline $\begin{array}{l}\text { Leadership } \\
\text { framework }\end{array}$ & $\begin{array}{l}\text { Kouzes \& Posner } \\
\text { Leadership Practices } \\
\text { Est. } 1985\end{array}$ & $\begin{array}{l}\text { Bass Transformational and } \\
\text { Transactional Leadership } \\
1985\end{array}$ & $\begin{array}{l}\text { Gardner's Tasks of } \\
\text { Leadership } 1990\end{array}$ & $\begin{array}{l}\text { Yukl's Framework for } \\
\text { Leadership } 2012\end{array}$ \\
\hline \multirow[t]{9}{*}{$\begin{array}{l}\text { Conceptual } \\
\text { dimensions of } \\
\text { leadership }\end{array}$} & $\begin{array}{l}\text { Inspire a shared } \\
\text { vision }\end{array}$ & Inspirational motivation & Explaining & $\begin{array}{l}\text { Giving/seeking } \\
\text { information: } \\
\text { - Monitoring } \\
\text { operations \& } \\
\text { environment } \\
\text { - Informing } \\
\text { - Clarifying roles } \\
\end{array}$ \\
\hline & $\begin{array}{l}\text { Inspire a shared } \\
\text { vision }\end{array}$ & Inspirational motivation & Motivating & $\begin{array}{l}\text { Influencing people: } \\
\text { - Motivating } \\
\text { - Recognizing and } \\
\text { rewarding }\end{array}$ \\
\hline & Encourage the heart & Individualized consideration & Renewing & \\
\hline & Enable others to act & Individualized consideration & $\begin{array}{l}\text { Achieving a } \\
\text { workable level of } \\
\text { unity }\end{array}$ & $\begin{array}{l}\text { Building } \\
\text { relationships: } \\
\text { - Networking } \\
\text { - Supporting } \\
\text { - Managing conflict } \\
\end{array}$ \\
\hline & $\begin{array}{l}\text { Challenge the } \\
\text { process }\end{array}$ & Intellectual stimulation & Envisioning goals & N/A \\
\hline & Model the way & Idealized influence & Serving as a symbol & $\mathrm{N} / \mathrm{A}$ \\
\hline & N/A & Idealized influence & $\begin{array}{l}\text { Representing the } \\
\text { group externally }\end{array}$ & $\mathrm{N} / \mathrm{A}$ \\
\hline & $\begin{array}{l}\text { Challenge the } \\
\text { process }\end{array}$ & Intellectual stimulation & Managing & $\begin{array}{l}\text { Making decisions: } \\
\text { - Planning and } \\
\text { organizing } \\
\text { - Problem solving } \\
\text { - Consulting and } \\
\text { delegating }\end{array}$ \\
\hline & Model the way & Individualized consideration & Affirming values & N/A \\
\hline
\end{tabular}

A directed approach to content analysis was chosen to review the selected textbooks. Directed content analysis is a structured technique and is a deductive rather than an inductive method for theory development (Potter \& Levine-Donnerstein, 1999). Variables and their relationships can be either confirmed or seen in new light, creating the potential to refine research questions and better hone the coding process. Since the goal of this analysis was to evaluate the relevance of existing leadership theory to the development and practice of nursing leadership, directed content analysis was deemed an appropriate method.

Directed content analysis begins by defining coding categories (Potter \& Levine-Donnerstein, 1999). To determine the most relevant codes for this analysis, the four major leadership theories used in nursing texts were analyzed (Table 1). While each of the four leadership frameworks labeled the dimensions of leadership differently, analysis of the core underlying concepts revealed common meaning (Table 1).

Selection of Gardner's (1990) nine tasks of leadership as an organizing framework for the qualitative coding was based on a number of factors that made it useful to nursing. First, Gardner's work has been used previously to organize leading behaviors in nursing clinical, management, and executive positions (Bleich \& Kist, 2015). 
Furthermore, Gardner (1990) recognized the effects of large systems on the ability to lead successfully, and he identified leadership as necessary at all levels of an organization. Since nursing is often provided within large, organized healthcare systems, and since accomplishment of current goals for innovation and patient safety require multi-level and multi-disciplinary leadership, Gardner's (1990) tasks of leadership are particularly appropriate for nursing. Further supporting this decision was the fact that his work defines nine discrete tasks, stated simply and practically. Having a larger number of distinct, easily understood coding categories reduces the likelihood of failing to capture diverse and unique elements in the leadership process, thus increasing trustworthiness of the analysis. Gardner's work is also pragmatic. Since nursing is a practice discipline, establishing clear, practical, and definable behaviors is pertinent. Hence, Gardner's nine tasks were used as the coding categories for this analysis.

The second step in directed content analysis is establishing an operational definition for each of the codes (Hsieh \& Shannon, 2005). Table 2 provides the operational definitions used for the coding in this directed content analysis. Operational definitions were determined by the authors after considering the work of nursing and

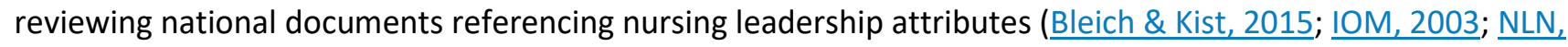
2009). Secondary review of the operational definitions was done by content experts outside of the author team. After establishing operational definitions, directed content analysis requires determining the data sample, which can be drawn from interviews or texts (Hsieh \& Shannon, 2005). In this analysis, the selected nursing leadership

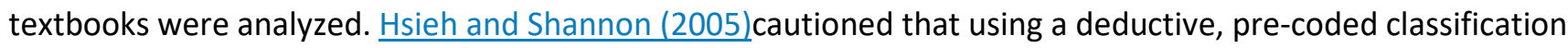
system may result in researcher bias, forcing identified concepts into pre-defined categories, and it might result in oversight of distinct themes or an additional category essential to the concept. For this reason, a log of outlier concepts was maintained by both authors.

Table 2. Operational definitions of coded nursing leadership tasks.

\begin{tabular}{|c|l|}
\hline $\begin{array}{c}\text { Directed content analysis } \\
\text { code (leadership task) }\end{array}$ & \multicolumn{1}{|c|}{ Operational definition } \\
\hline Envisioning goals & Asserting a vision of what nursing and healthcare can be at its best \\
\hline Affirming values & $\begin{array}{l}\text { Using professional values as a framework for practice through ongoing critical } \\
\text { reflection and examination of congruence in behavior and attitudes }\end{array}$ \\
\hline Motivating & Moving others to action \\
\hline Managing & $\begin{array}{l}\text { Organizing, coordinating, and implementing nursing care delivery that achieves } \\
\text { positive outcomes }\end{array}$ \\
\hline $\begin{array}{c}\text { Achieving a workable level } \\
\text { of unity }\end{array}$ & $\begin{array}{l}\text { Integrating various roles and functions among different people with multiple views } \\
\text { and opinions such that they can work together for a common goal or need }\end{array}$ \\
\hline $\begin{array}{c}\text { Explaining } \\
\text { Serving as a symbol }\end{array}$ & $\begin{array}{l}\text { Communicating to promote understanding and see connections previously not } \\
\text { seen }\end{array}$ \\
\hline $\begin{array}{c}\text { Representing the group } \\
\text { externally }\end{array}$ & $\begin{array}{l}\text { Articulating and sharing nursing's standpoint on improving health, the } \\
\text { environment, and the health care system }\end{array}$ \\
\hline Renewing & Caring for, strengthening, and developing self and others \\
\hline
\end{tabular}

Each author conducted a separate review, creating a table of findings organized around the codes. The researchers then met to compare findings. None of the content coded as outliers related to knowing and doing leadership; rather it discussed various contextual variables such as laws, regulation, reimbursement and other health system concepts typically discussed in prelicensure leadership courses. The directed content analysis confirmed that Gardner's (1990) nine tasks were inclusive of all of the knowing and doing currently incorporated into nursing leadership texts. 
Conceptualizing Being capable of leading in nursing

Possession of the requisite skills to lead is of no value if an individual does not perceive leading as a critical dimension of nursing practice or if the individual does not label themself a leader. To practice leadership in any role in nursing, individuals must not only know how to lead, but must also believe they can lead; thus, leadership development is integrally related to identity development (Day, Harrison, \& Halpin, 2009). Leadership identity development has been considered an essential component of formal leader development programs for some time (Day \& Harrison, 2007; Lord \& Hall, 2005) and has been acknowledged for consideration in nursing (Scott \& Miles, 2013). Komives, Longerbeam, Owen, Mainella, and Osteen (2006) used grounded theory to create a leadership identity development model relevant for college students. The model is stage-based, noting progression that is non-linear, complex and cyclical. Table 3 provides an overview of these stages of leadership identity development.

Table 3. Leadership identity development model - Adapted from Komives et al., 2006.

\begin{tabular}{|c|c|c|}
\hline Stage & Critical attributes & Transition \\
\hline Stage one: Awareness & $\begin{array}{l}\text { Recognition that leadership occurs in the } \\
\text { world }\end{array}$ & $\begin{array}{l}\text { Acknowledgement by an adult that } \\
\text { the student has leadership potential }\end{array}$ \\
\hline Stage two: Exploration & $\begin{array}{l}\text { Experiencing self in relationship to peers and } \\
\text { groups }\end{array}$ & $\begin{array}{l}\text { Students recognizes leadership } \\
\text { ability in themselves }\end{array}$ \\
\hline $\begin{array}{l}\text { Stage three: Leader } \\
\text { identified }\end{array}$ & Defining leadership as a position or role & $\begin{array}{l}\text { Student realizes leader aptitude but } \\
\text { need for others to accomplish goals }\end{array}$ \\
\hline $\begin{array}{l}\text { Stage four: Leadership } \\
\text { differentiated }\end{array}$ & $\begin{array}{l}\text { Changing from seeing leadership as a position } \\
\text { to also seeing leadership in individuals } \\
\text { without a formal leader role }\end{array}$ & $\begin{array}{l}\text { Student commits to a belief, goal or } \\
\text { purpose for which they will lead }\end{array}$ \\
\hline Stage five: Generativity & Committing to a cause beyond self & $\begin{array}{l}\text { Student serves as a mentor and } \\
\text { recruiter of others }\end{array}$ \\
\hline $\begin{array}{c}\text { Stage six: } \\
\text { Integration/synthesis }\end{array}$ & $\begin{array}{l}\text { Realizing the ability to lead from any position } \\
\text { or any place in a group }\end{array}$ & $\begin{array}{l}\text { Student values interdependence } \\
\text { and working effectively with others }\end{array}$ \\
\hline
\end{tabular}

Leadership identity development informed the Social Change Model of Leadership Development, which includes central assumptions that 1 ) leadership is collaborative, 2) leadership is a process rather than a position, 3 ) leadership should be value-based, 4) everyone is a potential leader, and 5) service teaches leadership skill (Komives \& Wagner, 2009). This model resonated with the authors and with the leadership definition proposed for use with nursing students, and was congruent with nursing ethics and values, leading to the choice of the theory to elucidate the "being" elements of nursing leadership. The Social Change Model recognizes leadership as being intricately embedded in the individual, in groups, and in society (Komives \& Wagner, 2009). The individual perspective describes personal qualities that foster leadership. The group and societal view illuminates the essential goal of leadership as promoting positive change. Seven critical values inform the model and the individual perceptions that must be cultivated to lead. These are reviewed in Table 4.

Table 4. Critical values in the social change model of leadership - Komives et al., 2013.

\begin{tabular}{|c|l|}
\hline Critical values & \multicolumn{1}{|c|}{ Definitions } \\
\hline Consciousness of self & Awareness of personal beliefs, values and patterns of behavior \\
\hline Congruence & Consistent action based on personal values, attitudes and emotions \\
\hline Commitment & Passionate energy focuses on an activity or outcome beyond self \\
\hline Collaboration & Ability to promote group action around a value and/or ideal \\
\hline Common purpose & Enabling work aimed at shared goals and a common vision \\
\hline Controversy with civility & Acceptance of differences and conflict resolution through dialogue \\
\hline Citizenship & Active engagement in social change and community/civic responsibilities \\
\hline
\end{tabular}


The attributes established by the Leadership Identity Model (Komives et al., 2006) and the definitions used in the Social Change Model of Leadership (Komives et al., 2013) can be used to inform leadership education curricula in terms of establishing content, active learning components and outcome expectations that would demonstrate development of a leadership identity and the capacity for being a leader.

\section{Conceptualizing Context and contextual intelligence in nursing leadership}

Context forms the fourth dimension of the proposed leadership development model for nurses. This has been described as the background for events (Kutz, 2008). Context includes the follower's engagement with those leading, the sociocultural realities, gender biases, situational realities as well as the social, legal and political milieu. Avolio (2007) discussed historical context, proximal context and distal context. Historical context impacts current leadership by prejudicing followers and organizations as to what are suitable and effective ways to lead. Proximal context is the immediate situation surrounding leadership exchanges and includes the type of work that is done, as well as the characteristics of the workers, tasks, and units or departments within which leadership occurs. Distal context relates to the culture and circumstances that are more distant yet present in leader-follower transactions. Things such as organizational, social and political realities are elements of distal context. These three forms of context are particularly relevant for nursing since considerable research supports the role of the work environment as a variable impacting nursing and patient care outcomes. Nursing, a feminized and often subordinated profession, is greatly impacted by distal and historical contexts that continue to disempower the influence the discipline has on health care environments and outcomes (Manojlovich, 2007).

Hermeneutics teaches us that knowing the background and setting of any event is necessary for understanding and interpretation (Kutz, 2008). Nurses are aware that context is more than the environment in which care is delivered; it is also acknowledgement that patient care and the nursing process are impacted by varied patient perceptions, cultural differences, gender, religious beliefs and psychosocial factors. Kutz (2008) asserted that understanding how to decipher context in a situation is a critical leadership function, one which crosses roles and professions, and one which can be labeled contextual intelligence, "the ability to quickly and intuitively recognize and diagnose the dynamic contextual variables inherent in an event or circumstance and results in intentional adjustment of behavior in order to exert appropriate influence in that context" $(2008$, p. 23). Contextual intelligence is comprised of understanding the effects of the past, recognizing the interplay of current variables, and the ability to envision future success (Kutz, 2008).

Whether nurses are in formal roles of leadership or are at the bedside collaborating with other professionals, leading change and innovation and fostering best practices, they must be able to understand context. It is not enough to develop knowledge and skills equipping them in how to lead; nurses must also be able to know when to move an idea forward and alternatives to propose that might be accepted given the circumstances, history and context.

\section{Discussion: The Nursing Leadership Development Model and recommended application}

Fig. 1 offers a diagrammatic interpretation of the Nursing Leadership Development Model. The innermost circle is the focus for all nursing leadership, the ability to influence positive change in achieving the triple aim of cost effective, quality care that meets satisfaction standards and promotes population health (Berwick, Nolan, \& Whittington, 2008). Positive change is accomplished through application of nine leadership skills derived from Gardner's tasks (Gardner, 1990). Three of these skills are seated in personal abilities: affirming values, renewing, and envisioning goals. This personal knowing and doing must be accompanied by being-ness that is committed to consciousness of self, congruence of values and behavior and a commitment to making a difference in nursing. Building on individual capacity, leadership development also requires intra and inter-personal skill in and understanding of managing, explaining, achieving a workable level of unity, and motivating. These leadership tasks are synergistically enhanced by developing a sense of self that values collaboration, the 
development of a common purpose in nursing and the ability to honor controversy with civility. Finally, attributes essential for expanding nursing leadership capacity to enhance communities and societies necessitates learning to represent the discipline to others and to serve as a symbol of the discipline within the profession. Ultimately, knowing and doing are augmented by appreciating the roles of citizenship and professional, organizational, and societal service. Surrounding the knowing, doing, and being elements of the model is contextual intelligence; the ability to assess variables that will influence stakeholder perceptions and actions, as well as cultural constraints and facilitators, and use that assessment to develop preferred influencing strategies.

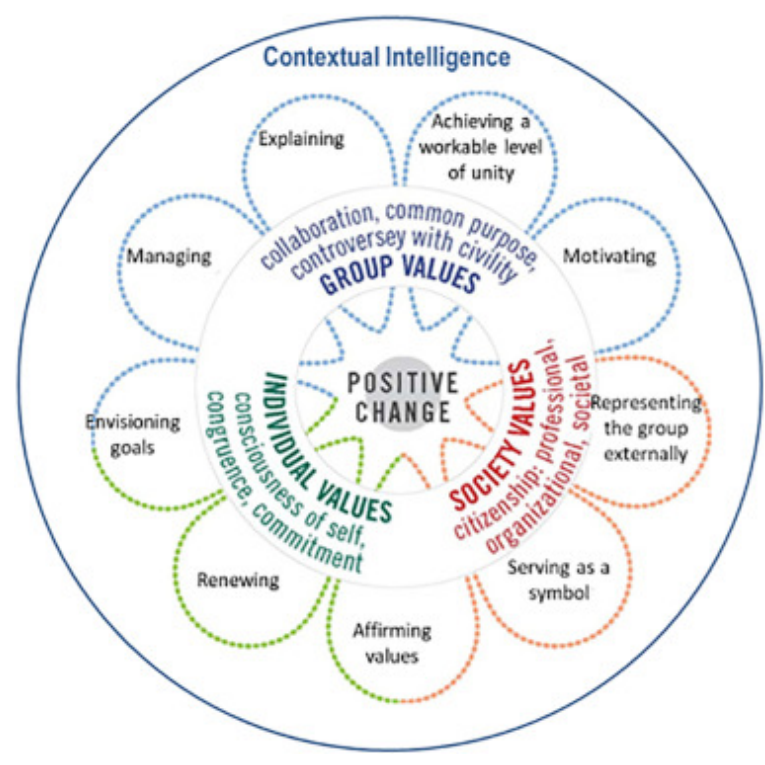

Fig. 1. Leadership development model.

This model can be used for guidance in structuring a leadership development curriculum for prelicensure nursing students. Rather than requiring nurse educators to adapt a single leadership theory, follow the format outlined within a textbook, or simply use experience to structure leadership education, use of this model will support structural consistency for leadership development across nursing education programs. Table 5 offers an example taken from a larger curriculum framework developed by the authors and based on the proposed leadership education model. It depicts the task of management and broadly outlines outcomes and skills in each of the knowing, doing and being domains. From this, nursing education programs would level the topics across the program curriculum, including within clinical experiences, rather than simply incorporating topics into one leadership course at the end of the program. Leveling would be guided by the primary domain (knowing, doing, being) associated with the topic, supporting decision making when designing courses and strategies to address each topic. Educators would be able to use a variety of strategies, but would use the domains of knowing, doing and being to determine appropriate use of such strategies to fit the outcomes expected for each domain.

Existing courses can be reviewed and compared to the model and to the leadership curriculum framework, and decisions can be supported regarding potential revisions. Choices of content and strategies should be evaluated based on their congruency not only with the tasks of leadership, but with the associated values and ability to drive positive change within the healthcare system.

Table 5. Example of leadership curriculum framework based on Nursing Leadership Education Model.

\begin{tabular}{|c|l|l|}
\hline Managing & \\
\hline $\begin{array}{c}\text { Definition: Organizing, } \\
\text { coordinating, and }\end{array}$ & & \\
\hline
\end{tabular}




\begin{tabular}{|c|c|c|}
\hline $\begin{array}{c}\text { implementing nursing care } \\
\text { delivery that achieves } \\
\text { positive outcomes. }\end{array}$ & & \\
\hline Knowing & $\begin{array}{c}\text { Doing - Skills at BSN level } \\
\text { (senior level) }\end{array}$ & Being/values \\
\hline $\begin{array}{l}\text { Define principles of } \\
\text { effective leadership and } \\
\text { management } \\
\text { - Theoretical frameworks } \\
\text { - Behaviors/skills } \\
\text { - Attitudes } \\
\text { - Styles } \\
\text { - Fostering Followership } \\
\text { - Ethical principles } \\
\text { - Roles and functions }\end{array}$ & $\begin{array}{l}\text { - Demonstrate a positive } \\
\text { influence on others } \\
\text { - Identify appropriate } \\
\text { and inappropriate } \\
\text { leadership and } \\
\text { management behaviors, } \\
\text { attitudes and styles } \\
\text { - Demonstrate situation- } \\
\text { appropriate role and } \\
\text { interactions } \\
\text { - Demonstrate } \\
\text { completion of assigned } \\
\text { responsibilities } \\
\text { - Apply leadership and } \\
\text { management concepts, } \\
\text { skills, and decision } \\
\text { making in the provision } \\
\text { of nursing care, } \\
\text { healthcare team } \\
\text { coordination, and the } \\
\text { oversight \& } \\
\text { accountability for care } \\
\text { delivery in a variety of } \\
\text { settings } \\
\text { - Assess personal } \\
\text { strengths and } \\
\text { weaknesses related to } \\
\text { management and } \\
\text { leadership in nursing } \\
\text { - Demonstrate ability to } \\
\text { apply ANA Code of Ethics }\end{array}$ & $\begin{array}{l}\text { - Common purpose } \\
\text { o Values inclusiveness } \\
\text { o Values interdependency of health care team } \\
\text { - Consciousness of self } \\
\text { o Appreciates personal strengths, challenges, } \\
\text { beliefs and values of self in relationship to } \\
\text { others } \\
\text { o Accepts accountability and responsibility for } \\
\text { nursing judgment and action } \\
\text { o Maintains awareness of emotional, } \\
\text { attitudinal, and behavioral response patterns } \\
\text { in self and others } \\
\text { - Demonstrate an appreciation for and commitment } \\
\text { to learning opportunities } \\
\text { - Recognize personal values and biases } \\
\text { - Acknowledge strengths and weaknesses } \\
\text { - Self-awareness of level of confidence in nursing } \\
\text { practice } \\
\text { - Take responsibility for behavior } \\
\text { - Recognize and accept interdependencies of } \\
\text { managers and staff } \\
\text { - Demonstrate appreciation for all nursing roles } \\
\text { including the nurse manager } \\
\text { - Demonstrate value for inclusiveness } \\
\text { - Appreciate interdisciplinary team members and } \\
\text { system resources } \\
\text { - Respect management chain of command } \\
\text { - Congruence } \\
\text { o Value caring behaviors } \\
\text { o Appreciate actions that contribute to } \\
\text { patient safety, quality care and healthy work } \\
\text { environments } \\
\text { o Value organizational engagement and } \\
\text { contribution } \\
\text { o Explain and describe examples of } \\
\text { supporting the mission, philosophy and vision } \\
\text { of both nursing and health systems } \\
\text { - Commitment }\end{array}$ \\
\hline
\end{tabular}

In addressing the dimensions of leadership in a manner that recognizes the developmental state of prelicensure students, educators can focus on facilitating development of a leadership mindset (Dyess \& Sherman, 2009), while selecting pedagogical approaches that can be flexibly adapted to the unique context of the nursing program and the needs of its students.

The authors envision implementation of the model and curriculum framework in a manner similar to the implementation of Quality and Safety Education for Nurses (QSEN) initiative (Cronenwett et al., 2007), 
generating dialogue and sharing of practices as well as leadership education research to encourage faculty to participate in building a strong evidence base for leadership development education. As the model is implemented, further application for BSN completion students, graduate and staff development programs is expected.

\section{Conclusion}

Theory should be used practically to answer questions and address problems, and one purpose of theory is to provide a conceptual map (Rijsord, 2010). This article proposes a Nursing Leadership Development Model that will be helpful in developing curricular content and educational experiences to support development of leadership capacity in prelicensure nursing students. Furthermore, it offers a model that can be tested and evaluated to determine if it adequately informs the discipline and explains the components and processes of nursing leadership education needed to equip students to lead.

\section{References}

American Association of Colleges of Nursing (2008). The essentials of baccalaureate education for professional nursing practice. Washington, DC: Author.

American Association of Colleges of Nursing (2011). The essentials of master's education in nursing. Washington, DC: Author.

Antonakis, J., Avolio, B. J., \& Sivasubramaniam, N. (2003). Context and leadership: An examination of the ninefactor full-range leadership theory using the Multifactor Leadership Questionnaire. The Leadership Quarterly, 14, 261-295.

Avolio, B. J. (2007). Promoting more integrative strategies for leadership theory-building. American Psychologist, 62(1), 25-33.

Bass, B. M. (1985). Leadership and performance beyond expectation. New York: NY. Sage.

Berwick, D. M., Nolan, T. W., \& Whittington, J. (2008). The triple aim: Care, health, and cost. Health Affairs, 27(3), 759-769.

Bleich, M., \& Kist, S. (2015). Leading, managing, and following. In P. S. Yoder-Wise (Ed.). Leading and Managing in Nursing (pp. 2-22). (6th ed.). St Louis, MS: Mosby, Inc.

Bleich, M. R. (2011). Leading, managing, and following. In P. S. Yoder-Wise (Ed.). Leading and managing in nursing (pp. 3-23). (5th ed.). St. Louis, MO: Elsevier.

Center for Creative Leadership (2014). Future trends in leadership development [White Paper]. Retrieved from http://www.ccl.org/Leadership/pdf/research/futureTrends. pdf.

Cox, J. F., Pearce, C. L., \& Sims, H. P. (2003). Developing shared leadership, as well as directive and empowering leader behaviors, to extend the transactional-transformational leader behavior paradigm: Toward a deeper and broader agenda for leadership development. In S. Murphy, \& R. Riggins (Eds.). The future of leadership development (pp. 161-180). Mahwah, NJ: Lawrence Earlbaum.

Cronenwett, L., Sherwood, G., Barnsteiner, J., Disch, J., Johnson, J., Mitchell, P., ... Warren, J. (2007). Quality and safety education for nurses. Nursing Outlook, 55(3), 122-131. https://doi.org/10.1016/j.outlook.2007.02.006.

Cummings, G., Lee, H., MacGregor, T., Davey, M., Wong, C., Paul, L., \& Stafford, E. (2008). Factors contributing to nursing leadership: A systematic review. Journal of Health Services Research \& Policy, 13(4), 240-248. https://doi.org/10.1258/jhsrp. 2008.007154.

Curtis, E. A., de Vries, J., \& Sheerin, F. K. (2011). Developing leadership in nursing: Exploring core factors. British Journal of Nursing, 20(5), 306-309.

Curtis, E. A., Sheerin, F. K., \& de Vries, J. (2011). Developing leadership in nursing: The impact of education and training. British Journal of Nursing, 20(6), 344-352.

Day, D., \& Antonakis, J. (2012). The nature of leadership. Thousand Oaks, CA: Sage.

Day, D., Gronn, P., \& Salas, E. (2004). Leadership capacity in teams. The Leadership Quarterly, 15(6), 857-880. 
Day, D., \& Harrison, M. M. (2006). Leadership development. In J. H. Greenhaus, \& G.a. Callanan (Eds.). Encyclopedia of career development (pp. 457-461). Thousand Oaks, CA: Sage.

Day, D., \& Harrison, M. M. (2007). A multilevel, identity-based approach to leadership development. Human Resource Management Review, 17, 360-373.

Day, D., Harrison, M. M., \& Halpin, S. M. (2009). An integrative approach to leader development: Connecting adult development, identity, and expertise. New York, NY: Routledge.

Donaldson, S. K., \& Crowley, D. M. (1978). The discipline of nursing. Nursing Outlook, 26(2), 113-120.

Dyess, S. M., \& Sherman, R. O. (2009). The first year of practice: New graduate nurses' transition and learning needs. Journal of Continuing Education in Nursing, 40(9), 403-410. https://doi.org/10.3928/0022012420090824-03.

Foli, K. J., Braswell, M., Kirkpatrick, J., \& Lim, E. (2014). Development of leadership behaviors in undergraduate nursing students: A service-learning approach. Nursing Education Perspectives, 35(2), 76-82. http://0dx.doi.org.libus.csd.mu.edu/10.5480/ 11-578.1.

Gardner, J. W. (1990). On leadership. New York, NY: Free Press.

Grossman, S. C., \& Valiga, T. M. (2000). The new leadership challenge: Creating the future of nursing. Philadelphia, PA: F. A. Davis.

Hsieh, H. F., \& Shannon, S. E. (2005). Three approaches to qualitative content analysis. Qualitative Health Research, 15(9), 1277-1288.

Institute of Medicine (IOM) (2003). Keeping patients safe: Transforming the work environment for nurses. Washington, DC: The National Academies Press. Retrieved from https://www.iom.edu/Reports/2003/Keeping-Patients-Safe-Transforming-the-WorkEnvironment-ofNurses.aspx.

Institute of Medicine (IOM) (2011). The future of nursing: Leading change, advancing health. Washington, DC: The National Academies Press. Retrieved from http://www.nap. edu/catalog/12956.htm.

James, K. M. G. (2010). Incorporating complexity science theory into nursing curricula. Creative Nursing, 16(3), 137-142. https://doi.org/10.1891/1078-4535.16.3.137.

Komives, S. R., Longerbeam, S. D., Owen, J. E., Mainella, F. C., \& Osteen, L. (2006). A leadership identity development model: Applications from a grounded theory. Journal of College Student Development, 47(4), 401-418.

Komives, S. R., Lucas, N., \& McMahon, T. R. (2013). Exploring leadership: For college students who want to make a difference. San Francisco, CA: John Wiley \& Sons.

Komives, S. R., \& Wagner, W. (2009). Leadership for a better world: Understanding the social change model of leadership. San Francisco, CA: John Wiley \& Sons.

Kouzes, J. M., \& Posner, B. Z. (2007). The leadership challenge (4th ed.). San Francisco, CA: Jossey-Bass.

Kutz, M. (2008). Toward a conceptual model of contextual intelligence: A transferable leadership construct. Leadership Review, 8, 18-31.

Lord, R. G., \& Hall, R. J. (2005). Identity, deep structure and the development of leadership skill. The Leadership Quarterly, 16, 591-615.

Manojlovich, M. (2007). Power and empowerment in nursing: Looking backward to inform the future. The Online Journal of Issues in Nursing, 12(1) (Manuscript 1).

Middleton, R. (2013). Active learning and leadership in an undergraduate curriculum: How effective is it for student learning and transition to practice? Nurse Education in Practice, 13(2), 83-88. https://doi.org/10.1016/j.nepr.2012.07.012.

Muftic, L. R. (2009). Macro-micro theoretical integration: An unexplored theoretical frontier. Journal of Theoretical and Philosophical Criminology, 1(2), 33-71.

National League for Nursing (2009). Promoting excellence in nursing education to build a strong and diverse workforce. Retrieved from http://www.nln.org/aboutnln/pdf/nln_brochure_general.pdf.

Northouse, P. G. (2013). Leadership: Theory and practice (6th ed.). Los Angeles, CA: Sage.

Parse, R. R. (2001). Qualitative inquiry: The path of sciencing. Sudbury, MA: Jones \& Bartlett Publishers. 
Pearce, C. L., \& Conger, J. A. (Eds.). (2003). Shared leadership: Reframing the hows and whys of leadership. Thousand Oaks, CA: Sage.

Pepin, J., Dubois, S., Girard, F., Tardif, J., \& Ha, L. (2011). A cognitive learning model of clinical nursing leadership. Nurse Education Today, 31, 268-273.

Phillips, J. M., Stalter, A. A., Dolansky, M. A., \& Lopez, G. M. (2016). Fostering future leadership in quality and safety in health care though systems thinking. Journal of Professional Nursing, 22(1), 15-24. http://0dx.doi.org.libus.csd.mu.edu/10.1016/j. profnurs.2015.06.003.

Pollard, C. L., \& Wild, C. (2014). Nursing leadership competencies: Low-fidelity simulation as a teaching strategy. Nurse Education in Practice, 14, 620-626. http://0-dx.doi. org.libus.csd.mu.edu/10.1016/j.nepr.2014.06.006.

Potter, W., \& Levine-Donnerstein, D. (1999). Rethinking validity and reliability in content analysis. Journal of Applied Communication Research, 27, 258-284.

Rijsord, M. (2010). Nursing knowledge: Science, practice, and philosophy. United Kingdom: Blackwell Publishing.

Scott, E. S. (2010). Perspectives on healthcare leader and leadership development. Journal of Health Care Leadership, 2, 83-90.

Scott, E. S., \& Miles, J. (2013). Advancing leadership capacity in nursing. Nursing Administration Quarterly, 37(1), 77-82. http://0-dx.doi.org.libus.csd.mu.edu/10. 1097/NAQ.0b013e3182751998.

Snook, A., Nohria, N., \& Khurana, R. (2012). The handbook for teaching leadership: Knowing, doing, and being. Thousand Oaks, CA: Sage.

Uhl-Bien, M. (2006). Relational leadership theory: Exploring the social processes of leadership and organizing. The Leadership Quarterly, 17(6), 654-676. https://doi.org/10. 1016/j.leaqua.2006.51007.

Waite, R., \& Brooks, S. (2014). Cultivating social justice \& leadership skills: A timely endeavor for undergraduate student nurses. Nurse Education Today, 34, 890-893.

Wassenaar, C. L., \& Pearce, C. L. (2012). The nature of shared leadership. In D. V. Day, \& J. Antonakis (Eds.). The nature of leadership (pp. 363-389). Thousand Oaks, CA: Sage.

Yoder-Wise, P. (2012). Preparing tomorrow's service leaders: An educational challenge. Nursing Administration Quarterly, 36(2), 169-178.

Yukl, G. (2012). Leadership in organizations (8th ed.). Upper Saddle River, NJ: Prentice Hall. 